\title{
Eusocial Apidae in Tropical Insular Region
}

\author{
Maria Cristina Affonso Lorenzon ${ }^{1 *}$, Marilena de Menezes Silva Conde ${ }^{2}$ and Celso \\ Guimarães Barbosa ${ }^{3}$ \\ ${ }^{I}$ Departamento de Ciência Animal; lorenzon@ufrrj.br; ${ }^{2}$ Departamento de Botânica; ${ }^{3}$ Departamento de Matemática; \\ Universidade Federal Rural do Rio de Janeiro; km 7; Rod. 465; 23890-000; Seropédica - RJ - Brasil
}

\begin{abstract}
This study examined species richness and relative abundance of eusocial Apidae in an insular region of rain-forest, southeastern Brazil. Sampling took place during one year, using an standardized method with entomological net, at sites of secondary growth habitats surrounded by Atlantic rain-forest. Thirteen species of eusocial Apidae were netted at flowers, over $80 \%$ of the captured individuals were meliponine species, although the presence of Apis mellifera, commonly dominant in Brazilian habitats. Foraging activity of these bee species were essentially nonseasonal, apparently affected by high humidity. The patterns in abundance and species richness observed in Ilha Grande differed with other studies conducted at tropical islands, which were characterized by the poverty of meliponine species.
\end{abstract}

Key words: Tropical rain forest, meliponine species, bee community, niche

\section{INTRODUCTION}

Meliponine is a pantropical group of eusocial bees, bearing at least 400 species (Kerr and Maule, 1964). Most species are restricted to neotropical regions (ca $75 \%$ of known species) and lack a functional sting (Michener, 2000). These species have permanent colonies often comprising large numbers of individuals which represent the main flower visitors and pollinators in tropical ecosystem (Roubik, 1989; Kerr et al., 2001). To maintain a genetic stability, a higher number of meliponine species's colonies are necessary, otherwise, these species would face a high probability of extinction (Kerr and Venkousky, 1982; Carvalho et al., 1995). Raw (1985) collected only $35 \%$ of the total number of Jamaican bees, that was collected by Heithaus (1979) in western Costa Rica. Roubik (1989) mentioned that in
Panamanian forested islands along the pacific coast there are only $15-20 \%$ of meliponine species occurring in similar areas in the adjacent mainlan. These results corroborated to expected species reduction on be islands communities, when compared with similar mainland community.

In Brazil, the predominance of meliponine species in number of individuals in mainland also contrasts with tropical islands, which is characterized by the poverty of meliponine species (Zanella et al., 1998). Thus, studies conducted in islands are worthwhile for comparing its structure with mainland communities, as elements for bee conservation (Sousa and Brown, 1994). In insular region, species richness, relative abundance and phenology, parts of a bee community structure, were studied, pointing out the hypotheses that this island followed the similar pattern with other islands already studied. These results were also

${ }^{*}$ Author for correspondence 
compared with the other similar surveys on island and mainland communities.

\section{MATERIALS AND METHODS}

The study was carried out in Ilha Grande State Park on the ocean-side Atlantic coast, southeastern Brazil $\left(23^{\circ} 09^{\prime} 05^{\prime} \mathrm{S}, 44^{\circ} 23^{\prime} \mathrm{W}\right)$ in 5,594 ha $(55.94$ $\mathrm{km}^{2}$ ). Ilha Grande lies about $20 \mathrm{~km}$ from the mainland and is clearly visible to humans on the mainland and has topographic high elevations, with highest point $1,031 \mathrm{~m}$. A presumable dry season lasts five months (from April to August), yearly mean temperature of $22.5^{\circ} \mathrm{C}$ and $2,242 \mathrm{~mm}$ of rainfall. It limits on the west by a chain of mountains called "Serra do Mar", which has a proteozoic formation.

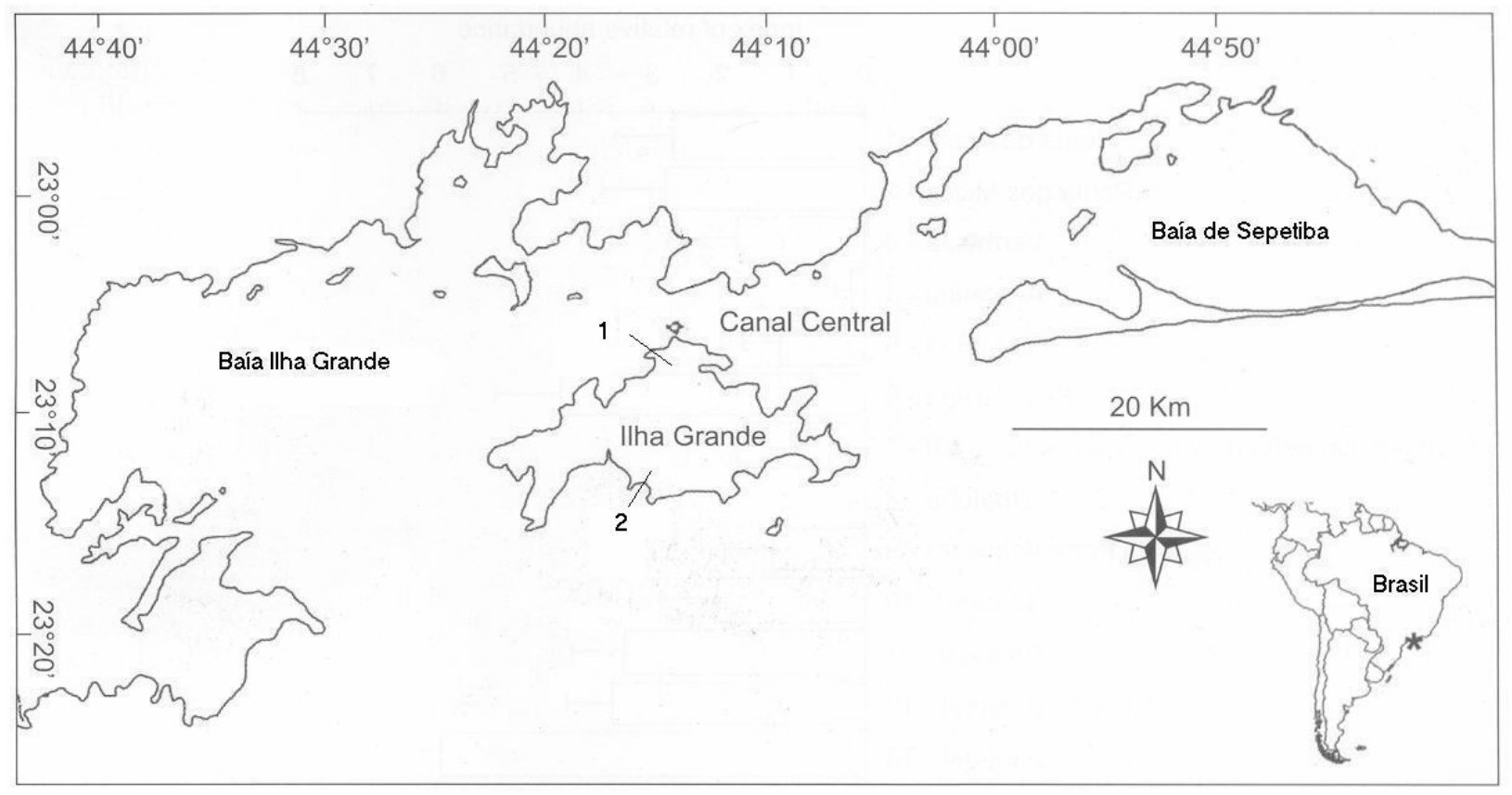

Figure 1 - Position of the studied sites in Ilha Grande

Surrounding the park, human community explores ecological tourism and is restricted to the rules of an state conservation system. The vegetation of Ilha Grande lies in the Atlantic Forest Morphoclimatic Domain (Ab'Saber, 1977) and largely supports a closed-canopy forest, called Dense Ombrofila Forest (47\%), a secondary growth forest $(43 \%)$, rocky outcrop, herbaceous, mangrove, salt marsh and beach vegetation (7\%) (Semads, 2001). In this forest, there are also some patches of human disturbance. The canopy is high, ranging from 30 to $40 \mathrm{~m}$ in height, and there are few reports on island vegetation.

Periodical sampling was made at four sites, using trials and dirt road, about $10 \mathrm{~m}$ from the forest edges and on the interface of the forest, which included some human influence and areas of welldeveloped forest. Two sites were towards mainland (site 1) and the two others ocean versant (site 2) (Fig. 1). Apparently the vegetation of the former was less exuberant than the latter. Restricted areas were delimited at each site and the same route was taken on each sampled day. Some parts of the sites presented some beach influence and stream vegetation and most observed vegetation was confined to the understory, or subcanopy, composed by climbers, liana, herbaceous and shrubs plants, i.e, most trees were difficult to access.

To evaluate the abundance, two collectors preferably caught eusocial bees while visiting flowers, or in flight with insect nets. Sampling started February 2002 and finished in January 2003, with two sampling at monthly intervals, at two sites chosen random, and sampled $6 \mathrm{~h}$ per day (6:00 to 12:00 AM). The minor effort was due to the humid and shadow conditions of the forest that caused sampling difficult. To reach the upper 
canopy, nets attached to long poles (about $7 \mathrm{~m}$ ) and, along yhe rivers, by climbing on the stones. Bee sampling was haphazard whenever flowering plants were encountered, considering as far as possible the overall abundance. Prolonged stay at a flower patch, more than $10 \mathrm{~min}$, was avoided. Thus, no flowering plant was particularly overrepresented in sampling. When a bee species was recognized, it was not captured, but numbered. The procedure for sampling was similar as recommended by Sakagami et al. (1967).

Relative bee abundance was examined by numbers of individuals, and species richness by numbers of species, both during foraging activity on flowers. Captured bees were killed with ethyl-acetate, identified and deposited at the Costa Lima Museum, Universidade Federal Rural do Rio de Janeiro and also at Fundação Instituto Estadual de Florestas.

Comparisons in terms of bee abundance and species richness involved: a) two sites towards the mainland and the ocean, b) two seasons, humid (from April to September) and rainy (from October to March), using Mann-Whitney U test for two variables analyses (Siegel and Castellas, 1988) at 5\% level of probability. The number of months that individuals visited flowers was considered an useful index as temporal specialization, as long as enough individuals of each species were observed, according to Heithaus (1979). The Berger-Parker index (d) was also used to measure the dominance degree at the studied sites (Magurran, 1988). The value of this index was done by using the equation $[\mathrm{d}=\mathrm{N} \max / \mathrm{N}]$, where (d) represented dominance degree, $(\mathrm{N}$ max) was the maximum number of individuals from the most abundant species divided by the total number of individuals $(\mathrm{N})$. The Berger-Parker index showed the most abundant species in proportional term from a certain sample. For additional local fauna characterizing, predominant species were compared for each studied site. These species were determined by taking the abundance in the whole area and divided by the total number of species collected, which represented the predominant species. Thus, each bee species abundance was compared to find out which were predominant.

\section{RESULTS}

In the studied sites, 12 native eusocial bee species residents were found, living in Ilha Grande. A total of 1860 specimens were captured with the following proportion for each species: Trigona sp. gr. fulviventris Guérin, 1835 (34.6\%), Partamona helleri Friese, 1900 (15.8\%), Trigona spinipes Fabricius, 1793 (11.8\%), Scaptotrigona bipunctata, Lepeletier, 1836 (11.9\%), Tetragonisca angustula, Latreille, 1811 (9.8\%), Melipona quadrifasciata anthidioides, Lepeletier, 1836 (1.8\%), M. rufiventris Lepeletier, 1836 (0.8\%), M. marginata carioca Moure, 1971 (0.7\%), Plebeia remota Holmberg, 1903 (1.2\%), P. droryana Friese, 1900, Cephalotrigona capitata Smith, 1854 (0.3\%), Leurotrigona muelleri Friese, $1900(0.1 \%)$, plus one introduced species, the Africanized honey bee, Apis mellifera (11\%). There was no published information about the introduction of honey bees in Ilha Grande, but inhabitants reported its introduction by beekeepers in 1970, although no species was allowed to introduce in Ilha Grande.

Considering the whole studied area, prevalent species were: a) site 1: T. fulviventris, $T$. spinipes, $P$. helleri, $S$. bipunctata; site 2 : only $T$. fulviventris. There was a difference between studied sites related to bee abundance. Site 1 comprised $73.34 \%$ of the specimens (MannWhitney U Test, $\mathrm{n}=12, P<0.05)$, but no difference for species richness was found ( $U$ test, $n=12$, $P \geq 0.05$ ), site 1 presented 13 species and site 2,12 species. The Berger-Parker index was 0.74 for site 1 and 0.26 for site 2 .

Some non-floral resources were collected only by some meliponine species: mud (P. helleri, $S$. bipunctata, T. fulviventris, $M$. quadrifasciata, $M$. rufiventris), resin ( $T$. spinipes, $T$. fulviventris, $T$. angustula, M. quadrifasciata), sweat (P. droryana, $P$. remota). The proportion of these species in these resources was $10 \%$. Apis mellifera was commonly foraging on artificial food sources, disturbing tourists when honeybees gathered for artificial sugars on garbage, sweets, soda, coffee, etc.

\section{Phenology}

Abundant rainfall yearly resembles Ilha Grande as an humid tropical ecosystem. In the studied sites and seasons (humid and rainy), the high frequency of eusocial species indicated non-seasonality $\left(\mathrm{X}^{2}\right.$, $P \geq 0.05$ ). Each month, foraging species and bee richness were similar in numbers, represented by at least three bee species and by at least nine plant species. The proportion of individuals, confined to 
the subcanopy and understory, comprised $32 \%$ of the total in humid period and produced $68 \%$ in rainy period and there was no difference between seasons (U-Test, $\mathrm{n}=6, P \geq 0.05$ ). March, June and October presented higher bee abundance. Each month, relative abundance was represented by at least 42 specimens; there were three drops, which coincided with collected days with high chance to rain, indicating how humid days interfered on bee foraging activity.

Most of species were well distributed along the year without a tendency to find out more species during rainy period since had more blossoms (U Test, $\mathrm{n}=6, P \geq .0 .05$ ). The major number of species occurred in April, October and November. T. fulviventris and $T$. spinipes showed distribution all over the year. L. muelleri, C. capitata, P. droyana and $P$. remota were collected in few months, commonly in rainy season. L. muerelli was represented by one specimen, probably because it was hard to observe this species while foraging.

\section{DISCUSSION}

Regarding the abundance of eusocial bees in Ilha Grande, there was an overwhelming dominance of meliponine species under Apis mellifera. Through a whole year, these species comprised over $89 \%$ of the bees collected in flowers and most of them were not prevalent, especially A. mellifera. Contrarily to other Brazilian habitats studied so far (e.g. Pedro and Camargo, 1991; Wilms and Wiechers 1997; Viana, 1999; Lorenzon et al., 2003), Africanized honeybee was not the dominant species. In Ilha Grande, honey bees were observed foraging mainly near resident's buildings and they were not common in the flowers which occurred in the forest. In Cayos Cochinos Island, Bermingham et al. (1998) observed honeybees strongly depending on alien plants in scarcity period and abundant, when native melittophilous flowers were exuberant. According to Wilms et al. (1996), Apis mellifera was also predominant and adapted well to the Atlantic rain forest of the mainland, differently from what was occurring at Ilha Grande.

Eusocial bees also gathered non-floral resources, especially mud and resins by stingless bees and artificial resources by Apis mellifera on human community. Therefore, the proportion of these species was lower foraging these resources $(10 \%)$ than flowers, they can be an important source for attending their niche. Certainly, detritus represent a rich source of food in rain-forest and need better investigation as recommended by Lorenzon and Matrangolo (2005).

A significant difference between relative abundance at the studied sites pointed out that the site towards mainland was more homogeneous. The difference occurred because there was more predominant species at this site, indicating better conditions to maintain eusocial bees. If this pattern persists, it can be an important trend in bee structure in this island. Some climatic or ecological factors might decrease bee abundance on the site towards ocean versant, which needed to be better investigated.

In others two Brazilian islands of southeastern region, Zanella et al. (1998) observed a decrease in diversity for Apidae, especially for meliponine species. This group was only represented by $P$. droryana, $P$. remota and $T$. angustula, while 13 meliponine species were observed in the mainland, which were T. fuscipennis, T. spinipes, $P$. helleri, T. fulviventris guianae, and S. xanthotricha the commonest species at the mainland. They supported the hypothesis of density compensation in island bee community, when meliponine species could be replaced by Halictidae species. Although Halictidae was not evaluated in Ilha Grande, several other non-highly eusocial Apidae were observed. However, Halictidae did not seem more abundant than meliponine species counterparts.

Data of Ilha Grande were closer to Wilms et al. (1996), the nearest study at adjacent mainland. These authors found out 16 species in Atlantic rain-forest: Paratrigona subnuda, $P$. droryana, $P$. helleri, S. bipunctata, T. spinipes, T. fulviventris, $T$. angustula, $P$. remota, $P$. nigriceps, $M$. quadrifasciata, $M$. rufiventris, M. marginata, C. capitata, L. muelleri, Schwarziana quadripunctata; the first five stingless bees' species were the most abundant. Morgado (2006) reported two species in ilha Grande, not presented in our study: Paratrigona lineata Lepetelier 1836 and Geotrigona sp., increasing the species composition from 12 to 14 species.

The structure of the eusocial bee fauna in Atlantic rain-forest of Ilha Grande showed differented from other neotropical mainland regions and islands. Since meliponines species are native in Ilha Grande, it was possible those species came from the mainland a long time ago. The presence of aggressive bee species and a poor presence of 
crossing water gaps to reach the mainland (Kerr and Maule, 1964), corroborated to these approach. According to Lamego (1945) and Semads (2001), Ilha Grande could be more than seven million years old, time since sea level rose to flood part of the coastal plain forming several islands. At that time, Ilha Grande was not an island, but part of the mainland, because its geological origin was related to that of the neighboring mainland. This report could help explaining how eusocial meliponines species existe in Ilha Grande.

\section{Phenology}

Undoubtedly Ilha Grande had a 12-month-flight season, since bee individuals and the majority of species were found all over the year, suggesting a lack of significant temporal partitioning and an expressive adaptation to rain-forest.

In general, flowering periods of plants reflected seasonality from bee abundance, but in Ilha Grande, it was hard to express because bees were not captured from high canopy. Aggressive stingless, like $T$. spinipes and $T$. fulviventris, with high populations, stressed its distributions all over the year. Some species, like L. muelleri and $C$. capitata, were in low proportion, also pointed out by Wilms et al. (1996) in rain-forest at mainland and also by Silveira and Campos (1995) in other kind of vegetation. The distribution of $P$. remota was the only one species different from other Brazilian islands (Zanella et al., 1998), which were more abundant. Their nests were also difficult to find out in Ilha Grande. Most C. capitata, $P$. remota and $P$. droryana occurred in rainy season probably due to herbaceous flowering plants, more common along the road in this period.

Although much of the ecology and the evolution of islands has been published, much remains to be studied, as occurred in Ilha Grande, especially about bees and their hosts. There is an increasing urgency to focus on this subject because insular species are being lost, and those being maintained, present uncommon breeding system, which is very important for conservation and restoration purposes.

\section{ACKNOWLEDGEMENTS}

This study was supported by FAPERJ. We are grateful to Fundação Instituto Estadual de Florestas (IEF-Rio) for allowing this work. Special thanks go to Dra. Sílvia R. de M. Pedro, from
Universidade de São Paulo (Ribeirão Preto, São Paulo) for identifying meliponine species and to Carolina S. Garcia for collecting plants and bees. We also thank the Universidade Estadual do Rio de Janeiro for allowing the use of the study sites.

\section{RESUMO}

Esta pesquisa foi realizada em uma Ilha tropical do Sudeste brasileiro, onde se examinou a riqueza em espécies e sua abundância relativa de abelhas Apidae eussocias. A amostragem foi feita durante um ano, com pulçás entomológicos, utilizando-se método padrão de coleta em regiões de habitat secundário, cercado por floresta de mata Atlântica. Treze espécies de abelhas eussociais foram capturadas nas flores, mais de $80 \%$ do total de espécimes eram meliponíneos, apesar da presença de Apis mellifera, comumente dominante nos hábitats brasileiros. O forrageamento das espécies de abelhas apresentou-se asazonal, com forte influência de períodos muito úmidos. Na Ilha Grande, padrões de abundância e riqueza em espécies contrastam com estudos realizados em outras ilhas, que se caracterizam pela baixa ocorrência de meliponíneos.

\section{REFERENCES}

Ab’Saber, A. N. (1977), Os domínios morfológicos na América do Sul. Geomorfologia, 52, 1-21.

Bermingham, E; Coates, A.; Cruz, G. D.; Emmons, L.; Foster, R. B.; Leschen, R.; Seutin, G.; Thorn, S.; Wcislo, W. and Werfel, B. (1998). Geology and terrestrial flora and fauna of Cayos Cochinos, Honduras. Revista de Biologia Tropical, 46 : (Supll.), 1-13.

Carvalho, G. A.; Kerr, W. E. and Nascimento, V. A. (1995), Sex determination in bees. XXXIII. Decrease of xo heteroalleles on a finite population of Melipona scutellaris (Apidae, Meliponine speciese). Rev. Bras. Genet., 18, 13-16.

Heithaus, E. R. (1979), Community structure of neotropical flower visiting bees and wasps: diversity and phenology. Ecology, 60, 90-202.

Kerr, W. E.; Carvalho, G. A.; Coletto da Silva, A. and Assis, M. G. P. (2001), Aspectos pouco mencionados da biodiversidade amazônica. Parcerias Estratégicas, 12, 1-22.

Kerr, W. E. and Maule, V. (1964), Geographic distribution of stingless bees and its implications (Hymenoptea: Apidae). J. New York Entomological Society, 62, 2-18. 
Kerr, W. E. and Venkousky, R. (1982), Melhoramento Genético em Abelhas. I. Efeito do número de colônias sobre o melhoramento. Rev. Bras. de Genética, 5, 279-285.

Lamego, A. R. (1945), O homem e o brejo. Rio de Janeiro: IBGE.

Lorenzon, M. C. A.; Matrangolo, C. R A. and Schoereder, J. H. (2003), Flora visitada pelas abelhas eussociais (Apidae), na Serra da Capivara em caatinga do sul do Piauí. Neotropical Entomology, 32, 37-45.

Lorenzon, M. C. A. and Matrangolo, C. R A. (2005), Foraging on some nonfloral resources by stingless bees (Hymenoptera, meliponine species) in caatinga region. Braz. J. of Biology, 65, 1-9.

Magurran, A. E. (1988), Ecological diversity and its measurement. Princeton: University Press.

Michener, C. (2000), The bees of the world. Baltimore: Jonhs Hopkins University Press.

Morgado, L. (2006), Biologia floral, fenologia, reprodutiva e guilda de abelhas (Hymenoptera, Apoidea) visitantes florais de quatro espécies simpátricas dde Tillandsia (Bromeliaceae) na Ilha Grande, Rio de Janeiro. DSc Thesis, Universidade Estadual do Estado do Rio de Janeiro, Rio de Janeiro.

Pedro, S. R. M. and Camargo, J. M. F. (1991), Interactions on floral resource between the Africanized honey bee Apis mellifera L. and the native bee community (Hymenoptera, Apoidea) in a "cerrado" ecossystem in southeast Brazil. Apidologie, 22, 397-415.

Raw, A. (1985), The ecology of Jamaican bees (Hymenoptera). Revista Brasileira de Entomologia, 29, 1-16.

Roubik, D. W. (1989), Ecology and natural history of tropical bees. New York: University Press.

Sakagami, S. F.; Laroca, S. and Moure, J. S. (1967), Wild bee biocenotics in São José dos Pinhais (PR), South Brazil. Preliminary report. Journ. Fac. Sci. Hokkaido University, Series VI, Zool., 16, 253-291.

Semads. (2001), Atlas das Unidades de Conservação da Natureza do Estado do Rio de Janeiro. Rio de Janeiro: Metalivros.

Siegel, S. and Castellas Jr., N. J. (1988), Non parametric statistics for the behavioral sciences. New York: McGraw-Hill.

Silveira, F. S. and Campos, M. J. O. (1995), A melissofauna de Corumbataí (SP) e Paraopeba (MG) e uma análise da biogeografia das abelhas do cerrado brasileiro (Hymenoptera, Apoidea). Rev. Bras. Entomol., 39, 371- 401.

Sousa, O. E. E. and Brown, V. K. (1994), Effects of habitat fragmentation on Amazonian Termite Communities. J. Trop. Ecol., 10, 197-206.
Viana, B. F. (1999), A comunidade de abelhas (Hymenoptera: Apoidea) das dunas interiores do Rio São Francisco, Bahia. An.. Soc. Entomol. Bras., 28, 635-645.

Wilms W.; Imperatriz-Fonseca, V. L. and Engels, W. (1996), Resource partitioning between highly eusocial bees and possible impact of the introduced africanized honey bee on native stingless bees in the Brazilian rainforest. Stud Neotrop.Fauna and Environm., 31, 137-151.

Wilms, W. and Wiechers, B. (1997), Floral resource partitioning between native Melipona bee and the introduced Africanized honey bee in the Brazilian Atlantic Rainforest. Apidologie, 28, 339-355.

Zanella, F. C. V.; Schwartz-Filho, D. L. and Laroca, S. (1998), Tropical bee island biogeography: diversity and abundance patterns. Biogeographica, 74, 103-115.

Received: January 17, 2005; Revised: July 11, 2005; Accepted: April 10, 2006. 